\title{
APLIKASI ALGORITMA GENETIKA DALAM MENGOPTIMASI TUNED MASS DAMPER UNTUK MEREDUKSI GETARAN PADA GEDUNG AKIBAT BEBAN GEMPA
}

\author{
Deni Ariadi \\ Dosen Program Studi Teknik Sipil Fakultas Teknik \\ Universitas 17 Agustus 1945 Samarinda, \\ Email: deniariadi.uajy@ gmail.com / HP. 085828986790
}

\begin{abstract}
ABSTRAK
Pergerakan tanah (gempa) merupakan salah satu beban yang dapat menyebabkan kerusakan pada struktur. Sementara itu di Indonesia merupakan daerah rawan gempa sehingga menuntut perlunya pertimbangan untuk membangun struktur bangunan yang tahan dan adaptif terhadap beban gempa. Oleh sebab itu, evaluasi total kinerja struktur bangunan sangat penting untuk dilakukan. Redaman adalah fenomena yang ada dalam setiap struktur, fenomena tersebut dapat mengurangi getaran yang disebabkan oleh kekuatan eksternal untuk diterapkan sistem struktur. Berbagai jenis peredam telah dikenal dewasa ini, salah satunya adalah Tuned Mass Damper (TMD) dimana sistem ini menerapkan konsep kontrol pada struktur. Tuned mass damper (TMD) telah banyak digunakan untuk mengendalikan getaran dalam sistem teknik mesin. Dalam beberapa tahun terakhir teori TMD telah diadopsi untuk mengurangi getaran pada gedung-gedung tinggi dan struktur teknik sipil lainnya. Peredam dinamis dan tuned mass damper adalah realisasi dari untuk aplikasi mengontrol getaran struktur. Unsur-unsur inersia, daktail dalam perangkat tersebut adalah: massa, pegas dan dashpot (atau redaman material). Konfigurasi lain seperti pendulum/peredam, dan peredam cair (liquid), juga telah digunakan untuk aplikasi pengurangan getaran. TMD melekat pada struktur untuk mengurangi respon dinamik dari struktur. Frekuensi damper diatur ke frekuensi struktural tertentu sehingga ketika frekuensi yang kuat, damper akan beresonansi dengan gerakan struktural. Massa biasanya melekat pada bangunan melalui sistem pegas - dashpot dan energi diuraikan oleh dashpot sebagai gerak relatif berkembang antara massa dan struktur. Konsep yang dipergunakan dalam algoritma genetika adalah mengikuti apa yang dilakukan oleh alam. Hasil optimasi pada aplikasi ini menunjukkan bahwa, optimasi TMD pada struktur bangunan menggunakan algoritma genetika dapat mengoptimalkan sifat peredam dengan efektif. Pada penelitian ini menggunakan bentuk struktur portal sederhana 2D dengan derajat kebebasan banyak (MDOF). Dengan optimasi menggunakan algoritma genetika kita dapat dengan mudah mencapai parameter yang akan kita inginkan, dengan mengoptimasi nilai kekakuan (kd) dan redaman (cd). Penggunaan TMD yang disimulasikan pada struktur yang mengalami gempa El Centro 1940, Northridge 1994 dan Kobe 1995. Menunjukkan bahwa TMD yang digunakan mampu mengurangi atau meredam getaran-getaran dan perpindahan pada struktur.
\end{abstract}

Kata kunci: optimasi, tuned mass damper, algoritma genetika, gempa. 


\begin{abstract}
Ground movement (earthquake) is one of the loads that can cause damage to structures. Meanwhile, Indonesia is an earthquake prone area, so it demands consideration to build a building structure that is resistant and adaptive to earthquake loads. Therefore, it is very important to evaluate the total performance of the building structure. Damping is a phenomenon that exists in every structure, this phenomenon can reduce vibrations caused by external forces to be applied to the structural system. Various types of dampers are known today, one of which is the Tuned Mass Damper (TMD) where this system applies the concept of control to the structure. Tuned mass dampers (TMD) have been widely used to control vibration in mechanical engineering systems. In recent years the TMD theory has been adopted to reduce vibrations in tall buildings and other civil engineering structures. Dynamic dampers and tuned mass dampers are the realization of the application for controlling the vibration of structures. The inertia and ductile elements in the device are: mass, spring and dashpot (or material damping). Other configurations, such as pendulums, and liquid absorbers (liquid), have also been used for vibration reduction applications. TMD is attached to the structure to reduce the dynamic response of the structure. The damper frequency is set to a certain structural frequency so that when the frequency is strong, the damper will resonate with the structural movement. Mass is usually attached to buildings via a spring-dashpot system and energy is broken down by the dashpot as relative motion develops between the mass and the structure. The concept used in genetic algorithms is to follow what nature does. The optimization results in this application indicate that, optimization of TMD in building structures using a genetic algorithm can optimize dampening properties effectively. In this study, a simple 2D portal structure with multiple degrees of freedom (MDOF) was used. By optimization using genetic algorithms we can easily achieve the parameters we want, by optimizing the stiffness $(k d)$ and damping $(c d)$ values. With the optimization process using a genetic algorithm the value of the population size strongly determines the speed of achieving iterations in the optimization process, the greater the popsize we determine, the faster iterations will be to achieve a convergence of the maximum fitness values obtained. The use of simulated TMD on structures that experienced the El Centro earthquake of 1940, Northridge 1994 and Kobe 1995. It shows that the TMD used is able to reduce or dampen vibrations and displacements in the structure.
\end{abstract}

Keywords: Optimization, Tuned Mass Damper, Genetic Algorithm, Earthquake.

\title{
PENDAHULUAN
}

Algoritma genetika merupakan metode pencarian yang disesuaikan dengan proses genetika dari organisme organisme biologi yang berdasarkan pada teori evolusi Charles Darwin. Algoritma genetika pertama kali ditemukan oleh John Holland, itu dapat dilihat dalam bukunya yang berjudul Adaption in Natural and Artificial Systems pada tahun 1975 dan kemudian dikembangkan bersama murid dan rekan kerjanya di Universitas Michigan pada tahun 1960-an sampai 1970-an. Tujuan Holland mengembangkan Algoritma Genetika saat itu bukan untuk mendesain suatu algoritma yang dapat memecahkan suatu masalah, namun lebih mengarah ke 
studi mengenai fenomena adaptasi di alam dan mencoba menerapkan mekanisme adaptasi alam tersebut ke dalam sistem komputer. (Fariza, dkk 2006).

Algoritma Genetika yang dibuat Holland merupakan sebuah metode untuk memisahkan satu populasi kromosom (terdiri dari bit-bit 1 dan 0) ke populasi baru dengan menggunakan "seleksi alam" dan operator genetik seperti crossover, mutation, invertion. Crossover menukar bagian kecil dari dua kromosom, mutation mengganti secara acak nilai gen di beberapa lokasi pada kromosom, invertion membalikkan urutan beberapa gen yang berurutan dalam kromosom. Dasar teori inilah yang menjadi dasar kebanyakan program yang menggunakan algoritma genetika pada saat ini. (Fariza, dkk 2006).

Teknik optimasi dengan menggunakan algoritma genetika telah banyak digunakan peneliti-peneliti terdahulu untuk mengoptimasi suatu struktur agar menjadi lebih efisien. Algoritma genetika banyak digunakan pada masalah praktis yang berfokus pada pencarian parameter-parameter optimal. Mekanisme dari penggunaan algoritma genetika berasal dari teori seleksi alam Charles Darwin dimana hanya populasi yang mempunyai nilai fitness yang tinggi yang mampu bertahan. Algoritma genetika telah digunakan untuk memperoleh solusi nilai optimum dan menunjukkan kelebihannya untuk menemukan solusi nilai optimum untuk persoalan-persoalan yang kompleks.

Sebelumnya di dalam bidang teknik sipil, ada banyak yang lebih terdahulu meneliti di antaranya Arfiadi (2000), Arfiadi dan Hadi (2001). Populasi pada algoritma genetika merupakan calon solusi suatu permasalahaan. Populasi ini akan mengalami proses evolusi yang berdasarkan pada mekanisme populasi yang mempunyai nilai fitness tertinggi (Arfiadi, 2000). Populasi-populasi ini akan mengubah chromosome untuk menghasilkan keturunan melalui tahap pindah silang (crossover) dan mutasi (mutation) sehingga populasi tersebut bertahan pada generasi selanjutnya. Individu yang "baik" dapat diliat dari nilai fitness yang tinggi dan akan bertahan dan dipilih untuk menjadi populasi pada generasi selanjutnya. Populasi yang mempunyai nilai fitness yang rendah akan digantikan dengan populasi yang mempunyai nilai fitness yang tinggi. Tentu saja beberapa populasi dengan nilai fitness yang rendah akan bertahan untuk menjadi populasi pada generasi selanjutnya, hal ini terjadi hanya karena populasi tersebut "beruntung". Nilai rata-rata fitness pada populasi yang ada akan lebih baik daripada populasi sebelumnya.

Penelitian ini diharapkan dapat mengoptimalkan dari fitnees $(k d)$ dan damping $(c d)$. Menurut Arfiadi dan Hadi (2011), kombinasi antara optimasi dengan menggunakan algoritma genetika biner (binary genetic algorithm) dan algoritma genetika real (real genetic algorithm) dalam sebuah pengaturan disebut algoritma genetika hybrid (hybrid genetic algorithm).

\section{TINJAUAN PUSTAKA}

\section{Algoritma Genetika}

Hal-hal yang harus dilakukan dalam menggunakan algoritma genetika adalah:

1. Mendefinisikan individu, dimana individu menyatakan salah satu solusi (penyelesaian) yang mungkin dari permasalahan yang diangkat.

2. Mendefinisikan nilai fitness, yang merupakan ukuran baik-tidaknya sebuah 
individu atau baik-tidaknya solusi yang didapatkan.

3. Menentukan proses pembangkitan populasi awal.

4. Menentukan proses seleksi yang akan digunakan.

5. Menentukan proses perkawinan silang (cross-over) dan mutasi gen.

\section{Struktur Umum Algoritma Genetik}

Algoritma genetika memberikan suatu pilihan bagi penentuan nilai parameter dengan meniru cara reproduksi genetik, pembentukan kromosom baru serta seleksi alami seperti yang terjadi pada makhluk hidup. Algoritma Genetik secara umum dapat diilustrasikan dalam diagram alir berikut ini:

\section{Siklus Algoritma Genetika}

Siklus dari algoritma genetika pertama kali diperkenalkan oleh David Goldberg, dimana gambaran siklus tersebut adalah sebagai berikut :

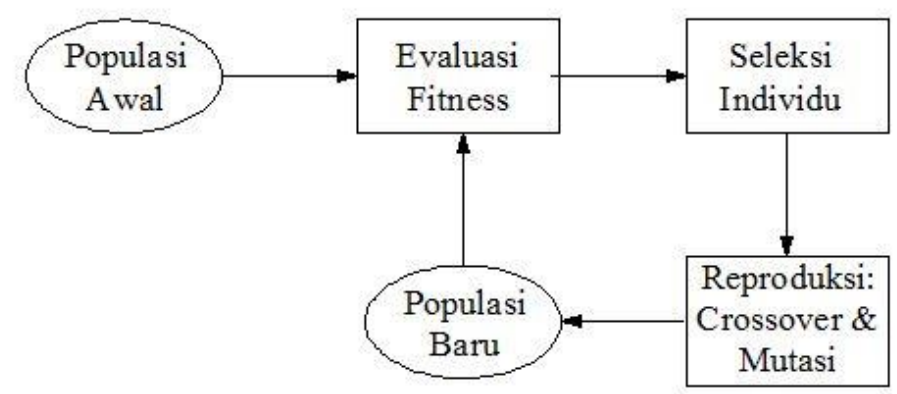

\section{Gambar 1. Siklus Algoritma Genetika Oleh David Goldberg}

Siklus ini kemudian diperbaiki oleh beberapa ilmuwan yang mengembangkan algoritma genetika, yaitu Zbignew Michalewicz dengan menambahkan operator elitism dan membalik proses seleksi setelah proses Reproduksi.

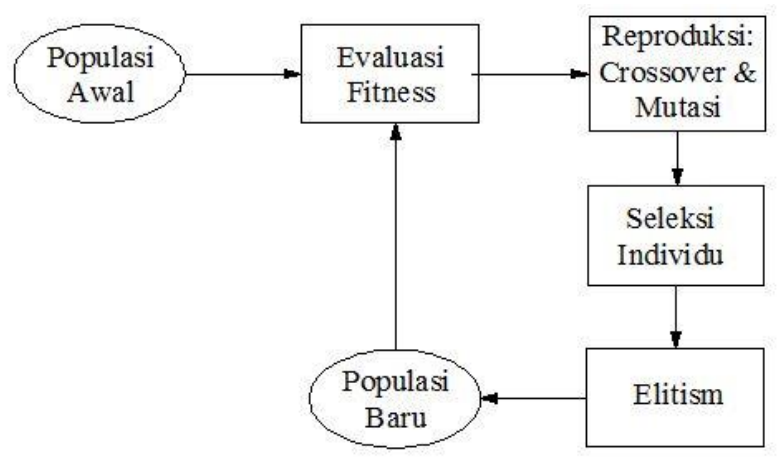

\section{Gambar 2. Siklus Algoritma genetika Yang Diperbarui Oleh Zbigne Michalewics}

\section{Algoritma Genetika Rill}

Algoritma genetik khususnya diterapkan sebagai simulasi komputer dimana sebuah populasi representasi abstrak (kromosom) dari solusi-solusi calon (individual) pada sebuah masalah optimisasi akan berkembang menjadi solusi-solusi yang lebih baik. 
Secara tradisional solusi-solusi tersebut dilambangkan dalam biner sebagai string '0' dan '1', walaupun dimungkinkan juga penggunaan penyandian (encoding) yang berbeda. Evolusi dimulai dari sebuah populasi individual acak yang lengkap dan terjadi dalam generasigenerasi. Dalam tiap generasi kemampuan keseluruhan populasi dievaluasi, kemudian multiple individuals dipilih dari populasi sekarang (current) secara stochastic (berdasarkan kemampuan mereka) lalu dimodifikasi (dengan mutasi atau rekombinasi) menjadi bentuk populasi baru yang menjadi populasi sekarang (current) pada iterasi berikutnya ari algoritma.

Teknik optimasi dengan menggunakan algoritma genetika telah banyak digunakan peneliti-peneliti terdahulu untuk mengoptimasi suatu struktur agar menjadi lebih efisien. Algoritma genetika banyak digunakan pada masalah praktis yang berfokus pada pencarian parameter-parameter optimal. Mekanisme dari penggunaan algoritma genetika berasal dari teori seleksi alam Charles Darwin dimana hanya populasi yang mempunyai nilai fitness yang tinggi yang mampu bertahan. Algoritma genetika telah digunakan untuk memperoleh solusi nilai optimum dan menunjukkan kelebihannya untuk menemukan solusi nilai optimum untuk persoalan-persoalan yang kompleks.

Sebelumnya didalam bidang teknik sipil, ada banyak yang lebih terdahulu meneliti di antaranya Arfiadi (2000), Arfiadi dan Hadi (2001). Populasi pada algoritma genetika merupakan calon solusi suatu permasalahaan. Populasi ini akan mengalami proses evolusi yang berdasarkan pada mekanisme populasi yang mempunyai nilai fitness tertinggi (Arfiadi, 2000). Populasi-populasi ini akan mengubah chromosome untuk menghasilkan keturunan melalui tahap pindah silang (crossover) dan mutasi (mutation) sehingga populasi tersebut bertahan pada generasi selanjutnya. Individu yang 'baik' dapat diliat dari nilai fitness yang tinggi dan akan bertahan dan dipilih untuk menjadi populasi pada generasi selanjutnya. Populasi yang mempunyai nilai fitness yang rendah akan digantikan dengan populasi yang mempunyai nilai fitness yang tinggi. Tentu saja beberapa populasi dengan nilai fitness yang rendah akan bertahan untuk menjadi populasi pada generasi selanjutnya, hal ini terjadi hanya karena populasi tersebut "beruntung". Nilai rata-rata fitness pada populasi yang ada akan lebih baik daripada populasi sebelumnya. Nilai fitness merepresentatifkan fungsi objektif dari persoalan yang sebenarnya yang ingin didapatkan. Ukuran dari keoptimalan suatu populasi diukur dengan fitness masing-masing populasi. Kondisi ini membuat algoritma genetika dapat digunakan untuk persoalan optimasi yang susah dan kompleks sehingga mendapatkan solusi yang optimum dengan menggunakan cara yang mudah.

Penelitian ini diharapkan dapat mengoptimalkan dari fitnees $(k d)$ dan damping $(c d)$. Untuk optimalisasi sifat TMD, RCGA dengan bilangan real yang digunakan secara langsung. Misalnya bagi seorang individu awal yang memiliki empat variabel desain, empat nomor acak yang dihasilkan seperti yang digambarkan pada Gambar 3.

$\overline { 1 0 . 5 } \longdiv { 0 . 5 } \longdiv { 2 2 . 9 } \overline { 1 2 . 1 }$

Gambar 3. Individu dengan 4 desain variabel RCGA 


\section{METODE PENELITIAN}

Meskipun ada banyak mutasi dan Crossover prosedur yang tersedia, crossover dan mutasi yang digunakan dalam penelitian ini diambil sebagai berikut.

Untuk individu G1 dan G2 diambil untuk Crossover, keturunan yang dihasilkan $\mathrm{G}_{1}$ dan $\mathrm{G}_{2}$ mengikuti apa yang disebut Crossover seimbang (Herrera et al. 1998) sebagai berikut:

$\mathrm{G}_{1}^{\prime}=\mathrm{a}\left(\mathrm{G}_{1}-\mathrm{G}_{2}\right)+\mathrm{G}_{1}$

$\mathrm{G}_{2}^{\prime}=\mathrm{a}\left(\mathrm{G}_{2}-\mathrm{G}_{1}\right)+\mathrm{G}_{2}$

di mana a = angka acak antara 0 dan 1 Hal ini dapat dilihat bahwa untuk RCGA dengan menggunakan metode crossover ini domain yang menarik untuk optimasi tidak perlu diketahui, sebagai crossover memiliki kemampuan untuk menjelajahi domain yang tidak diketahui (Arfiadi dan Hadi). Ini adalah kemampuan RCGA untuk menjelajahi domain yang tidak diketahui tujuan yang bertentangan dengan BCGA. Sebagaimana dapat dilihat di bawah ini pada contoh, desainer bisa menebak nilai awal untuk Variabel desain yang sangat acak tanpa mempengaruhi nilai desain akhir.

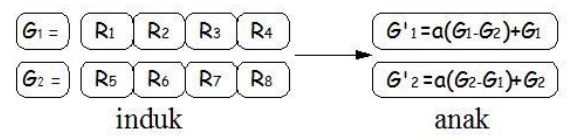

\section{Gambar 4. Keseimbangan crossover RCGA}

Untuk mutasi, variabel desain yang dihasilkan setelah mutasi sederhana adalah (Gambar 3):

$G_{p}^{\prime}=\left[\begin{array}{llllll}R_{1} & R_{2} & \ldots . & R_{j}^{\prime} & \ldots & R_{N}\end{array}\right]$

$\mathrm{R}_{\mathrm{j}}^{\prime}=\alpha \mathrm{a} \mathrm{R}_{\mathrm{j}}$

dimana $\alpha>1$, dan $\mathrm{a}=$ nomor acak antara 0 dan 1 .

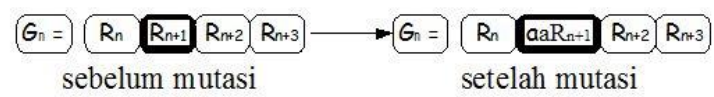

\section{Gambar 5. Proses mutasi}

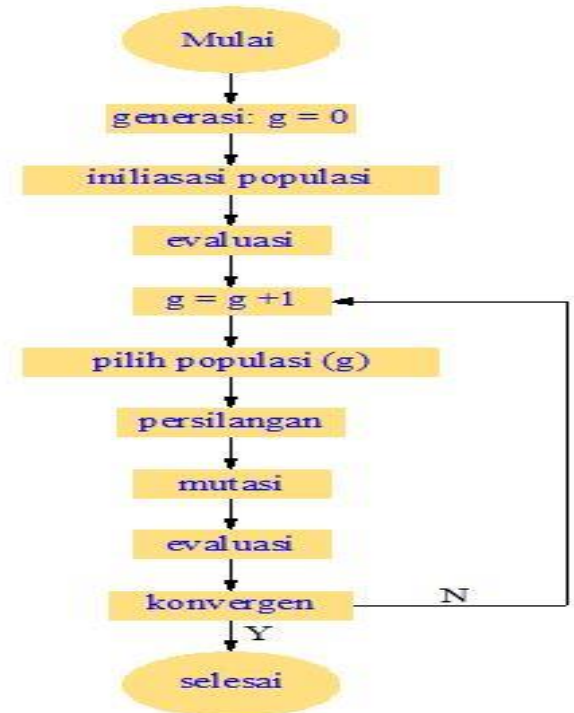

Gambar 6. Flowchart algoritma genetika 


\section{Struktur TMD Dengan Derajat Kebebasan Banyak (MDOF)}

Mempertimbangkan multi-degree-of-freedom (MDOF) struktur dengan TMD yang terikat pada lantai tertentu. Strukturnya diasumsikan sebagai bangunan geser dengan massa yang disamakan di masing-masing tingkat lantai. Persamaan dari gerakan tersebut dapat dituliskan sebagai berikut:

$$
M_{s} \ddot{X}_{s}+K_{s} \dot{X}_{s}=e_{s} \ddot{x}_{g}
$$

Dimana:

$$
\begin{aligned}
& M s=\operatorname{diag}\left[\begin{array}{lllll}
m_{1} & m_{2} & \ldots . & m_{N} & m_{d}
\end{array}\right] \\
& C s=C^{\prime}{ }_{o}+C^{\prime}{ }_{d} \\
& K s=K_{o}{ }_{o}+K^{\prime}{ }_{d} \\
& X s=\left[\begin{array}{lllll}
x 1 & x 2 & \ldots & x N & x d
\end{array}\right] \\
& e s=\left[\begin{array}{lllll}
-m 1 & -m 2 & \ldots .-m N & -m d
\end{array}\right]^{\mathrm{T}}
\end{aligned}
$$

Dimana $\mathbf{M}_{\mathbf{s}}, \mathbf{C}_{\mathbf{s}}, \mathbf{K}_{\mathbf{s}}$ adalah massa, redaman dan kekakuan matriks dari struktur, masing-masing: $\mathbf{X}_{\mathbf{s}}$ adalah pemindahan secara relatif dengan pengaruh tanah, $\ddot{\mathbf{X}}_{\mathrm{g}}$ adalah percepatan dari tanah ke gempa bumi, $\mathbf{e}_{\text {s adalah pengaruh gempa bumi pada }}$ bangunan struktur. Tanda titik dua merupakan penurunan dengan fungsi waktu. Dalam persamaan (6) $m_{l}=$ massa lantai ke- $i(i=1,2 \ldots, \mathrm{N}), m_{d}=$ massa redaman, $\mathbf{C}^{\prime}{ }_{\mathbf{o}}$ dalam persamaan (7) adalah $(\mathrm{N}+1) \times(\mathrm{N}+1)$ matrik redaman sebagai kontribusi dari $\mathbf{C}_{\mathbf{o}}, \mathbf{C}_{\mathbf{o}}=\mathrm{NxN}$ matrik redaman struktur tanpa TMD sebagai fungsi dari $c_{i}$, dimana $c_{i}=$ kelembaban lantai ke- $i(i=1,2 \ldots, \mathrm{N}), \mathbf{K}_{\mathbf{0}}^{\prime}$ dalam persamaan $(8)$ adalah $(\mathrm{N}+1 \mathrm{x}$ $(\mathrm{N}+1)$ kekakuan matriks sebagai kontribusi $\mathbf{K}_{\mathbf{o}}, \mathbf{K}_{\mathbf{o}}=\mathrm{N}$ x N matrik redaman struktur tanpa TMD sebagai fungsi dari $k_{i}=$ kekakuan tingkat ke- $i(i=1,2 \ldots, \mathrm{N})$.

Kontribusi TMD pada kekakuan matriks, $\mathrm{K}_{\mathrm{d}}^{\prime}$, yang diperoleh dari

$$
K_{d}=\left[\begin{array}{cc}
k_{d} & -k_{d} \\
-k_{d} & k_{d}
\end{array}\right]
$$

Dimana $k_{d}=$ kekakuan redaman, dengan vektor tujuan kekakuan redaman sebagai berikut :

$\mathbf{I D d}_{\mathbf{d}}=[\mathrm{jd} \quad \mathrm{N}+1]$

Dimana $j_{d}$ adalah nomor lantai pada lokasi TMD, dan $(\mathrm{N}+1)$ merupakan angka derajat kebebasan untuk TMD. Perlu diperhatikan bahwa $j_{d}$ tidak perlu menjadi lantai yang paling atas. Dengan menggunakan gambaran ini, proses pemasangan yang dilakukan boleh mengikuti proses pemasangan pada metode kekakuan matriks. Beberapa dapat diselesaikan dengan kontribusi redaman jika TMD mengubah $\mathbf{K}_{\mathbf{d}}$ dan $k_{d}$ seperti persamaan (6-10) dengan $\mathbf{C}_{\mathbf{d}}$ dan $c_{d}$, berturut-turut. Dengan cara yang sama $\mathrm{C}_{\mathrm{o}}^{\prime}$ dan $\mathrm{K}_{\mathrm{o}}$ dipasang untuk mendapatkan $\mathrm{C}_{\mathrm{o}}$ dan $\mathrm{K}_{\mathrm{o}}$ dengan vektor tujuan yang sesuai.

$Z=A Z+E w$ 
Dimana:

$Z=\left\{\begin{array}{c}\dot{X}_{s} \\ \ddot{X}_{s}\end{array}\right\}, A=\left[\begin{array}{cc}0 & I \\ -M_{s}^{-1} & -M_{s}^{-1} C_{s}\end{array}\right], E=\left\{\begin{array}{c}0 \\ M_{s}^{-1} e_{s}\end{array}\right\}$, dan $w=\ddot{x}_{g}$

Dengan persamaan yang dihasilkan

$\mathrm{z}=\mathrm{C}_{\mathrm{z}} \mathrm{Z}$

\section{Prosedur Optimasi GA-H2}

Tujuannya adalah untuk menentukan nilai optimum dari kd kekakuan dan cd redaman dari peredam yang meminimalkan fungsi transfer $\mathrm{H}_{2}$ norm dari gangguan eksternal pada keluaran yang diatur. Perpindahan relatif dari struktur sehubungan dengan tanah yang diambil sebagai output diatur sedemikian rupa.

Untuk menoptimalkan TMD massa dari TMD yang ditentukan, kemudian kekakuan dan redaman di optimalkan. Oleh karena itu setelah membentuk persamaan gerak, persamaan gerak kemudian diubah kedalam persamaan vector Z. Hasil keluaran z sebagai respon untuk meminimilkan kemudian dipilih kedalam hubungan dengan performa index. Permasalahan ini dapat ditunjukan sebagai berikut:

Diperoleh parameter TMD (kd,cd)

$\dot{\mathrm{Z}}=\mathrm{A} \dot{\mathrm{Z}}+\mathrm{E} w$

$\mathrm{Z}=\mathrm{C}_{\mathrm{z}} \mathrm{Z}$

$$
\left[\operatorname{tr}\left(C z L c C^{T} z\right)\right]^{1 / 2}=\left[\operatorname{tr}\left(E^{T} L o E\right)\right]^{1 / 2}
$$

Dimana $\mathrm{J}=A L c+L c A^{T}+E E^{T}=0 o r$

$$
A 1^{T} L o A+C^{T} z C z=0
$$

Perhitungan $\mathrm{H}_{2}$ norm dapat diperoleh dengan mudah menggunakan fungsi lyap dan norm pada perintah MATLAB Control System Toolbox. Algoritma genetika rill dapat digunakan untuk mengoptimalkan fungsi objektif. Bagaimanapun juga algoritma genetika rill biasanya cukup untuk mengoptimalkan parmeter TMD sebagai pencarian nilai dari kd dan cd.

\section{HASIL DAN PEMBAHASAN}

Diketahui bangunan 2 lantai sederhana dengan derajat kebebasan banyak (MDOF) terlihat pada gambar 7 yang digunakan dalam penelitian ini. Struktur diasumsikan sebagai bangunan geser. Untuk massa pada lantai sebesar $\mathrm{m} 1=140 \mathrm{t}, \mathrm{m} 2=140 \mathrm{t}$ dan kekakuan $\mathrm{k} 1=3.9 \times 10^{4} \mathrm{kN} / \mathrm{m}, \mathrm{k} 2=3.9 \times 10^{4}$. Matrix redaman dengan koefisien redaman $\mathrm{c} 1=249 \mathrm{kN}-\mathrm{det} / \mathrm{m}, \mathrm{c} 2=249 \mathrm{kN}-\mathrm{det} / \mathrm{m}$. Pada penelitian ini nilai massa redaman diambil sebesar $2 \%$ dari berat total massa, nilai optimum redaman dan kekakuan redaman menggunakan fungsi objektif $\mathrm{H} 2$ norm.

Sifat struktur dalam persamaan ini adalah : 


$$
\begin{aligned}
& {\left[\begin{array}{ccc}
m_{1} & 0 & 0 \\
0 & m_{2} & 0 \\
0 & 0 & m_{d}
\end{array}\right]\left\{\begin{array}{c}
\ddot{x} 1 \\
\ddot{x} \\
\ddot{x} d
\end{array}\right\}+\left[\begin{array}{ccc}
c_{1}+c_{2} & -c_{2} & 0 \\
-c 2 & c_{2}+c_{d} & -c d \\
0 & -c_{d} & c d
\end{array}\right]\left\{\begin{array}{c}
\dot{x} 1 \\
\dot{x} 2 \\
\dot{x} d
\end{array}\right\}+} \\
& {\left[\begin{array}{ccc}
k_{1}+k_{2} & -k_{2} & 0 \\
-k_{2} & k_{2}+c_{d} & -c d \\
0 & -c d & c d
\end{array}\right]\left\{\begin{array}{l}
x_{1} \\
x_{2} \\
x_{d}
\end{array}\right\}=\left\{\begin{array}{c}
f_{1}(t) \\
f_{2}(t) \\
0
\end{array}\right\}}
\end{aligned}
$$

Kontrol parameter algoritma genetika sebagai berikut :

Dimana $\mathrm{x} 1-\mathrm{x} 2=$ displacement pada tiap lantai

Nilai maximum dari generasi $=200$

Ukuran populasi $=5,10,15,20$

Probabilitas crossover $=0.45$

Probabilitas mutasi $=0.1$

Nilai populasi $=10 \%$ dari ukuran populasi.

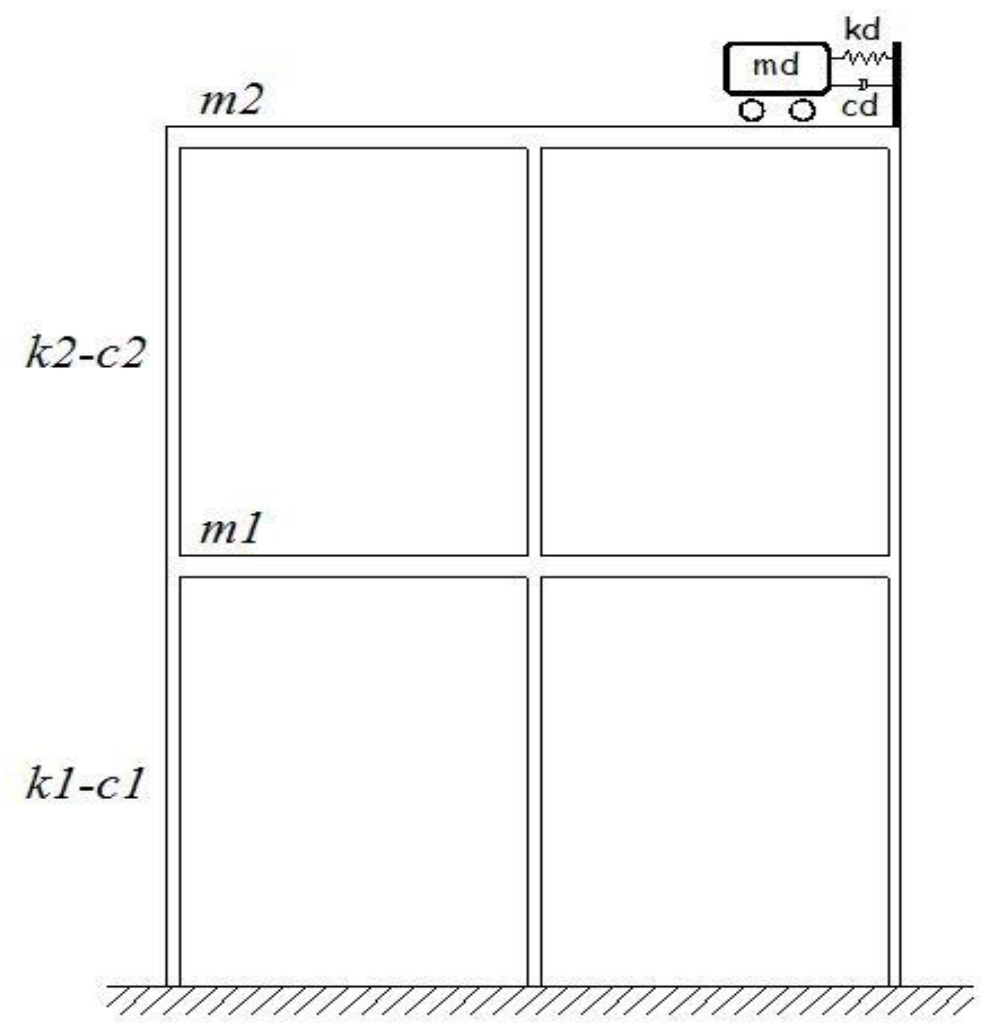

Gambar 7. Struktur Portal

Berikut beberapa percobaan optimasi dengan algoritma genetika dengan bantuan program Matlab, dengan Nilai maksimum dari generasi $=200$, Ukuran populasi yang digunakan bervariasi antara $=5,10,15,20$, Probabilitas crossover $=0.45$ Probabilitas mutasi $=0.1$ Nilai populasi $=10 \%$ dari ukuran populasi. 
JURNAL KACAPURI

JURNAL KEILMUAN TEKNIK SIPIL

Volume 4 Nomor 1 Edisi Juni 2021

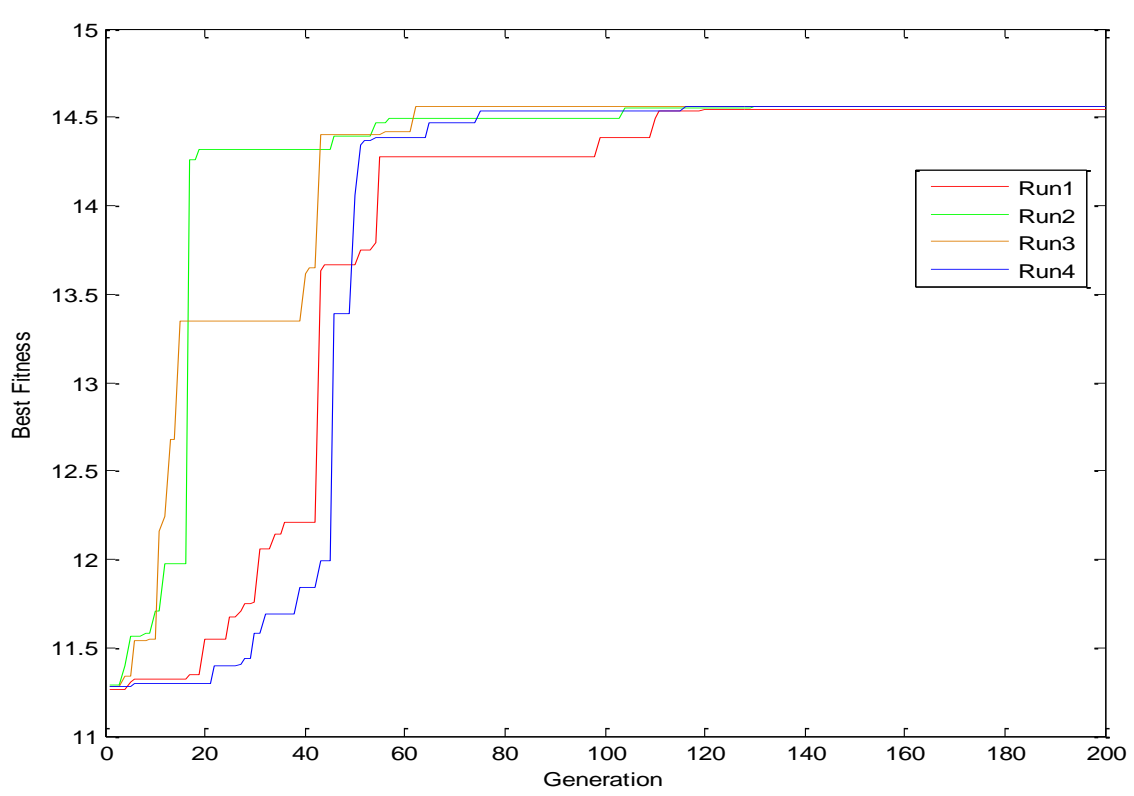

Gambar 8. Peningkatan best fitness setiap percobaan dengan ukuran populasi 5

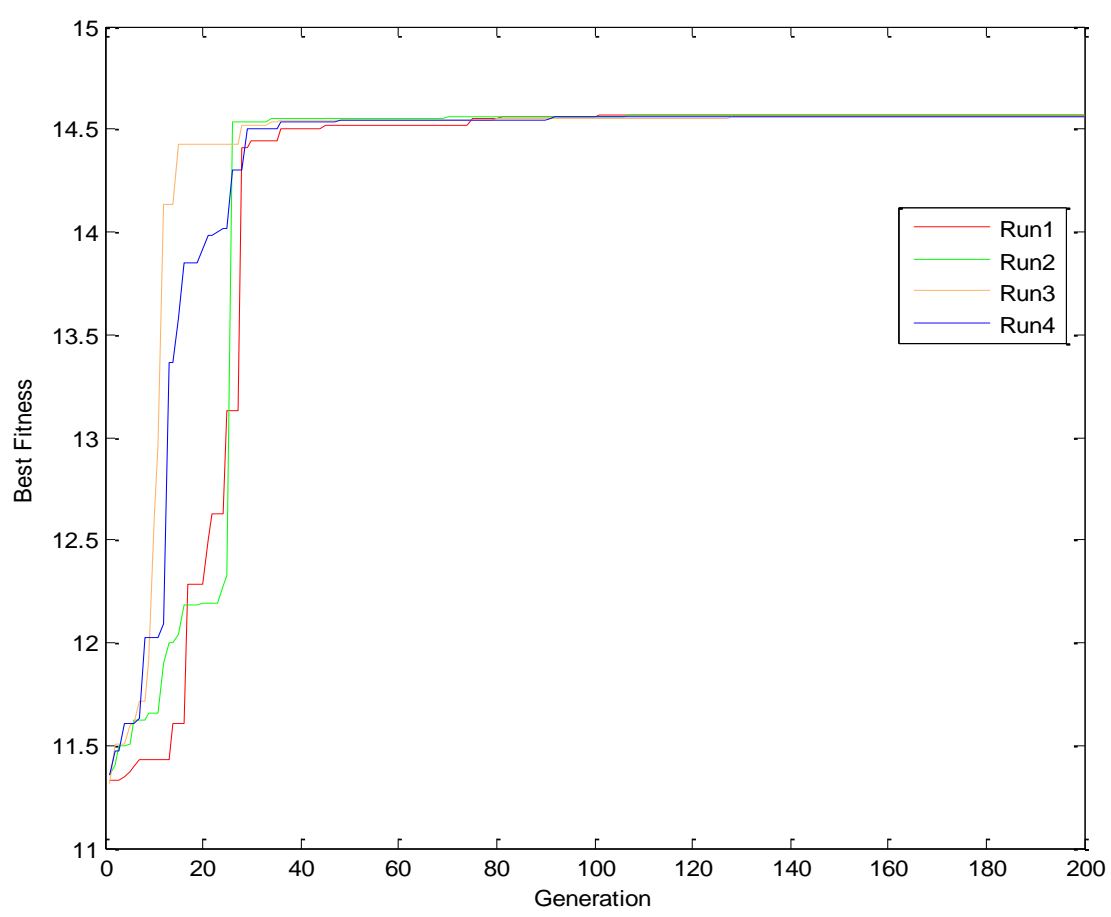

Gambar 9. Peningkatan best fitness setiap percobaan dengan ukuran populasi 10 
JURNAL KACAPURI

JURNAL KEILMUAN TEKNIK SIPIL

Volume 4 Nomor 1 Edisi Juni 2021

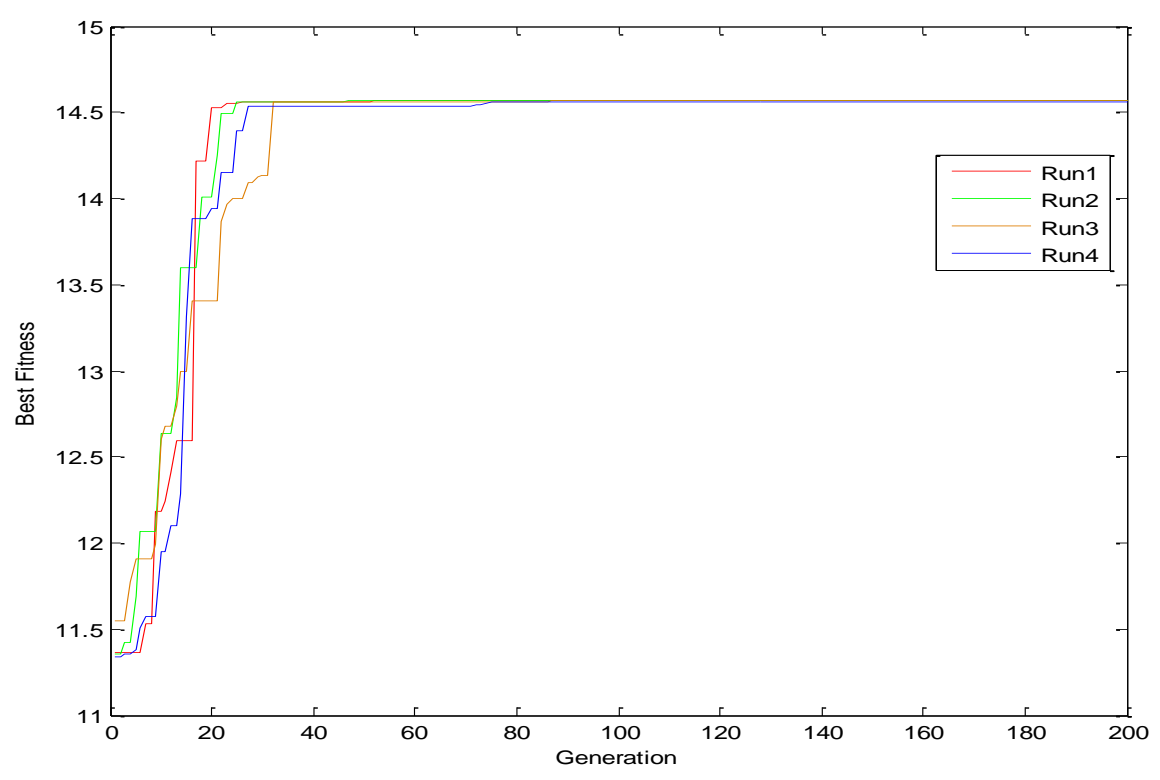

Gambar 10. Peningkatan best fitness setiap percobaan dengan ukuran populasi 15

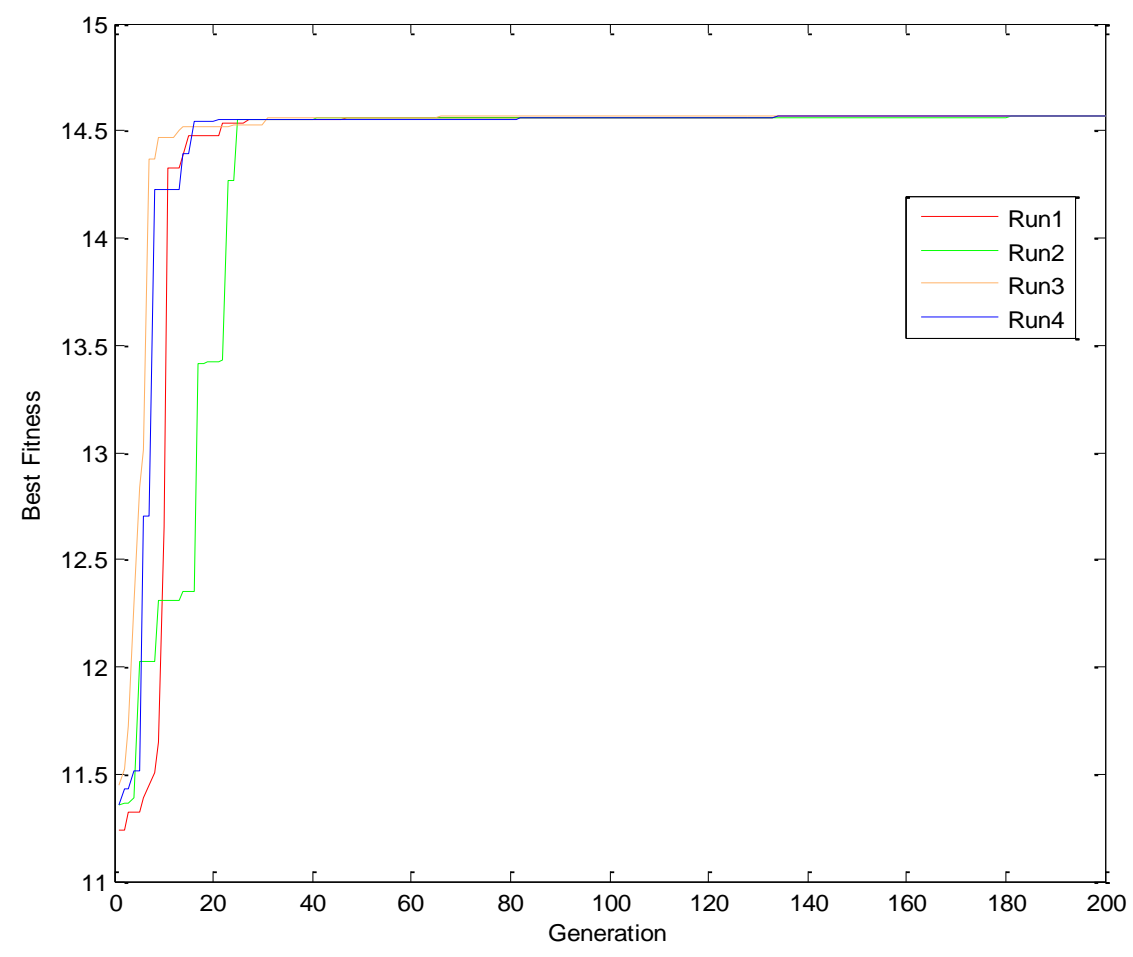

Gambar 11. Peningkatan best fitness setiap percobaan dengan ukuran populasi 20 
JURNAL KACAPURI

JURNAL KEILMUAN TEKNIK SIPIL

Volume 4 Nomor 1 Edisi Juni 2021

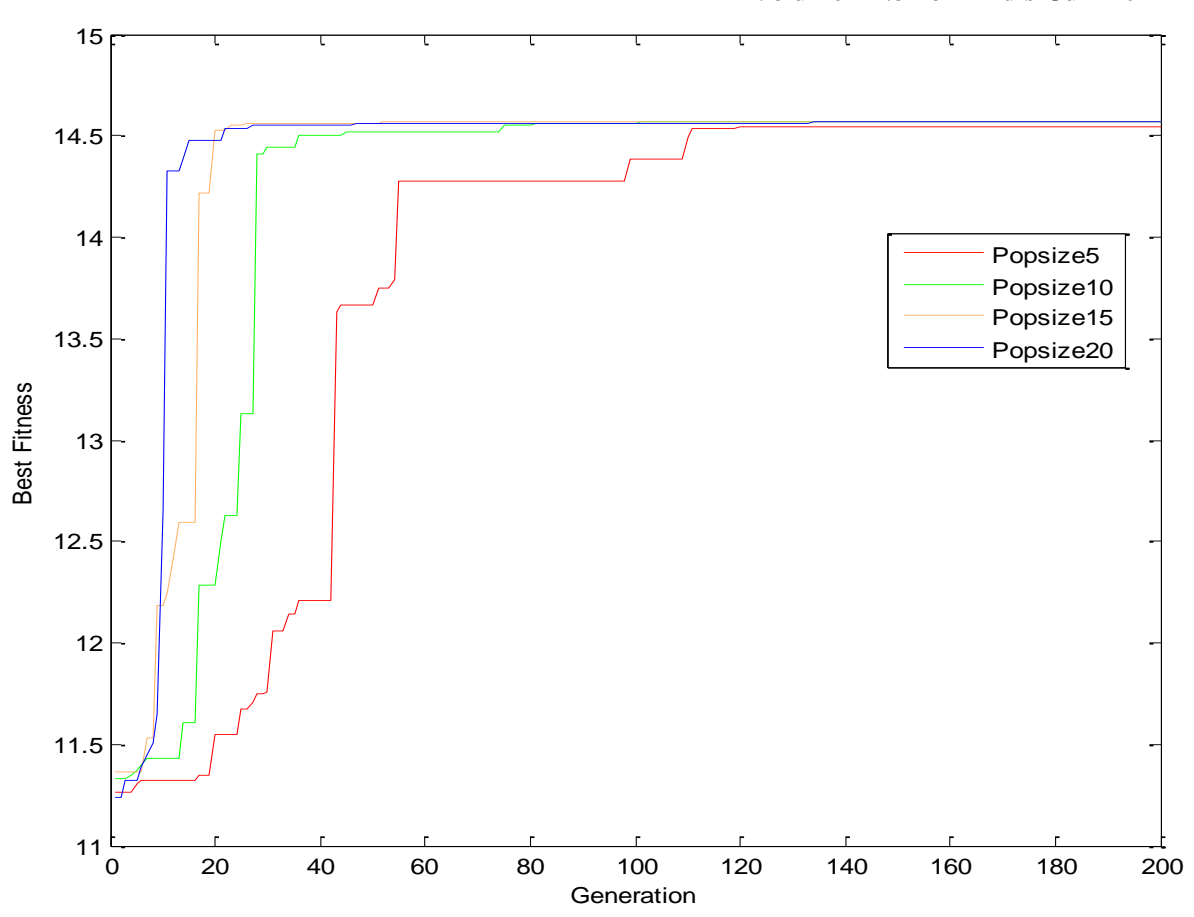

Gambar 12. Kombinasi best fitness

Tabel 1. Nilai maksimum fitness

\begin{tabular}{ccccc}
\hline \multirow{2}{*}{ Pop Size } & \multicolumn{4}{c}{ Max Fitness } \\
& Run 1 & Run 2 & Run 3 & Run 4 \\
\hline 5 & 14.5465 & 14.5643 & 14.5642 & 14.5619 \\
10 & 14.5654 & 14.5654 & 14.5627 & 14.5628 \\
15 & 14.5654 & 14.5652 & 14.5654 & 14.5647 \\
20 & 14.5653 & 14.5649 & 14.5652 & 14.5651 \\
\hline
\end{tabular}

Hasil optimasi yang diperoleh menggunakan algoritma genetika adalah : $\mathrm{kd}=$ $540.4533 \mathrm{kN} / \mathrm{m}, \mathrm{cd}=9.1557 \mathrm{kN} /$ det. Dari percobaan optimasi menggunakan algoritma genetika, dengan Nilai maximum dari generasi (population size) $=200$, Ukuran populasi (popsize) yang digunakan bervariasi antara $=5,10,15,20$, Probabilitas crossover $=0.45$ Probabilitas mutasi $=0.1$ Nilai populasi $=10 \%$ dari ukuran populasi.

Dengan menggunakan ukuran populasi yang bervariasi, terlihat pada saat iterasi maksimal fitness dari percobaan ukuran populasi 5, 10, 15, 20 memiliki konvergen yang berbeda-beda, semakin besar nilai ukuran populasi (popsize) maka semakin cepat tercapainya konvergen.

Dalam penggunaanya (TMD) cukup efektif dalam mereduksi getaran pada struktur yang terkena beban gempa, itu terlihat dari plot time history response dimana terlihat cukup jelas selisih perpindahan yang terjadi pada struktur yang mana menggunakan redaman dan tidak menggunakan redaman. Untuk melihat fungsi 
TMD dalam mereduksi getaran pada struktur akibat gempa, struktur ini disimulasikan mengalami gempa El Centro 1940, Northridge 1994 dan Kobe 1995. Hasil simulasi ditampilkan pada gambar 13-15 untuk time history response dari gempa El Centro 1940, Northridge 1994 dan Kobe 1995. Dari hasil perhitungan time history response dengan menggunakan nilai rasio massa $2 \%$ dan nilai kekakuan dan redaman yang sudah ditetapkan sebelumnya. Percobaan time history ini menggunakan bantuan program MATLAB 2013.

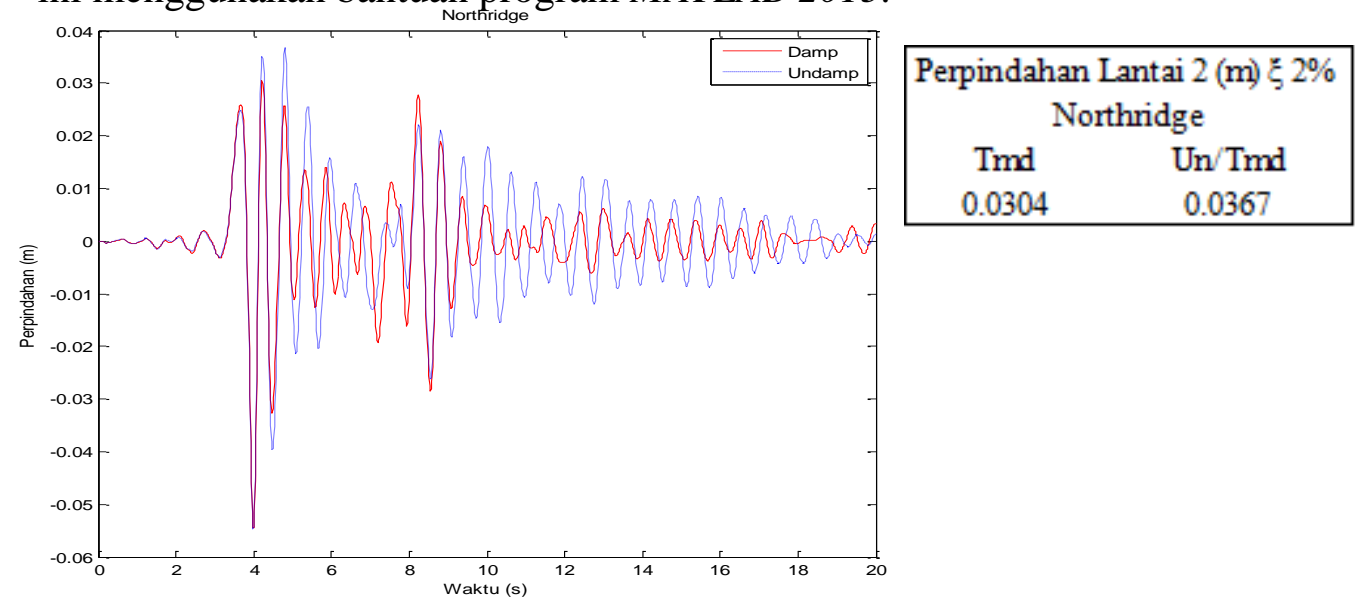

Gambar 13. Time History Gempa Northridge

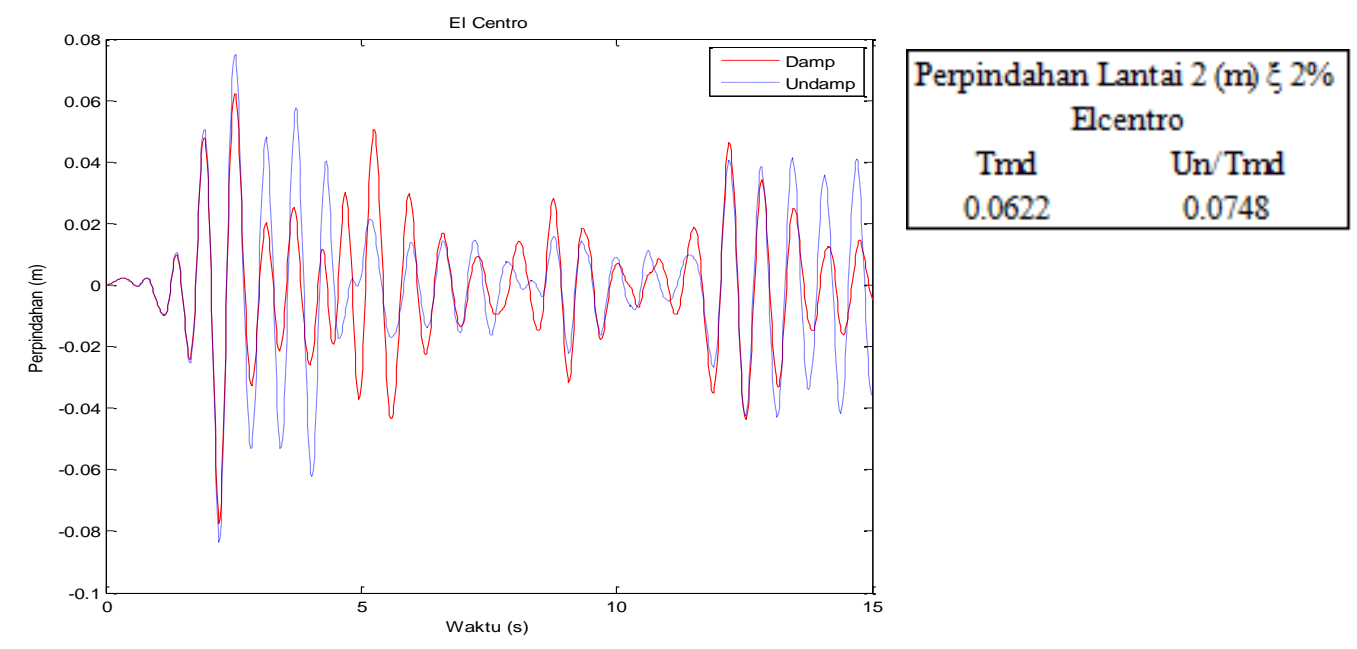

$\underset{\text { Kobe }}{\operatorname{Gambar} 14 .}$ Time History Gempa Elcentro

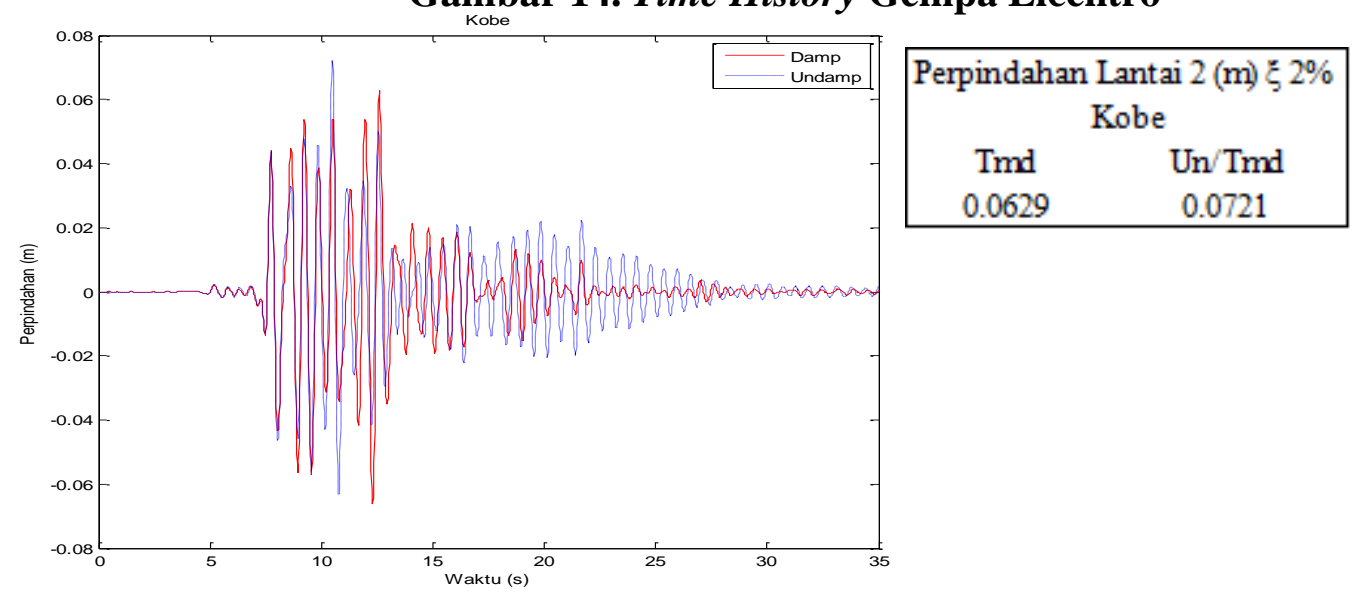

Gambar 15. Time History Gempa Kobe 


\section{PENUTUP}

\section{Kesimpulan}

Berdasarkan hasil analisis dan pembahasan dapat diambil kesimpulan sebagai berikut:

1. Dengan optimasi menggunakan algoritma genetika kita dapat dengan mudah mencapai parameter yang akan kita inginkan, dengan mengoptimasi nilai kekakuan (kd) dan redaman (cd). Dengan proses optimasi menggunakan algoritma genetika nilai dari ukuran populasi (population size) sangat menentekukan kecepatan pencapaian dalam proses optimasi, semakin besar popsize yang kita tentukan semakin cepat pula iterasi untuk mencapai konvergen nilai maksimal fitness yang didapat.

2. Dalam penggunaanya (TMD) cukup efektif dalam mereduksi getaran pada struktur yang terkena beban gempa, itu terlihat dari plot time history response dimana terlihat cukup jelas selisih perpindahan yang terjadi pada struktur yang mana menggunakan redaman dan tidak menggunakan redaman. Untuk melihat fungsi TMD dalam mereduksi getaran pada struktur akibat gempa, terlihat pada struktur yang disimulasikan mengalami kejadian gempa El Centro 1940, Northridge 1994 dan Kobe 1995, menunjukkan bahwa TMD yang digunakan mampu mengurangi atau meredam getaran-getaran dan perpindahan pada struktur.

\section{DAFTAR PUSTAKA}

1. Arfiadi, Y (2008). "Dual Active Tuned Mass Damper For Reducing Response Of Asymmetric Buildings", International Conference on Earthquake Engineering and Disaster Mitigation, Jakarta, April 14-15, 2008.

2. Arfiadi, Y (2014)."Buku Kuliah Dinamika Struktur Lanjut", Universitas Atma Jaya Yogyakarta.

3. Arfiadi, Y (2000)."Optimal Passive and Active Control Mechanisms For Seismically Exited Buildings", Universitas Of Wollongong Thesis Colection.

4. Arfiadi, Y. Hadi MNS (2001)."Optimal Direct (Static) Output Feedback Controller Using Real Coded Genetic Algorithms". International Journal of Computer and Structures, Vol.79 No. 17, 1625-1634.

5. Arfiadi, Y. Hadi MNS (2011). "Optimum placement and properties of tuned mass dampers using hybrid genetic algorithms.Int.J.Optim". Civil Eng.,1:167187.

6. Chopra A.K.(1997) "Dynamic Of Structure". International Edition.

7. Clough, R.W. dan Penzien, J. (1997)."Dinamika Struktur", jilid I. Penerbit Erlangga.Jakarta.

8. Hartog, D. J. P. (1947). "Mechanical vibrations". McGraw-Hill, New York, N.Y.

9. Widodo.(2000)."Respons Dinamik Struktur Elastik". UII Press Jogjakarta. Jogjakarta. 